Reprod. Nutr. Dévelop., 1983, 23 (6), 1043-1053.

\title{
Utilization of phosphorus and calcium and minimal maintenance requirement for phosphorus in growing sheep fed a low-phosphorus diet
}

\author{
A. BOXEBELD, L. GUÉGUEN (*), Geneviève HANNEQUART, Michelle DURAND
}

Station de Recherches de Nutrition, I.N.R.A., 78350 Jouy-en-Josas, France.

Summary. This paper reports the effects of a marginal phosphorus deficiency associated or not with an excess of calcium in $\mathbf{5}$ lots of $\mathbf{4}$ growing sheep each fed a semi-purified diet containing cellulose $(25-27 \%)$ and urea as the only nitrogen source.

In experiment 1, two P-deficient diets $(1.2 \mathrm{~g} / \mathrm{kg} \mathrm{DM})$ poor (LPLCa) or rich (LPHCa) in $\mathrm{Ca}$ led to lower phosphatemia, decreased appetite and a negative or zero $\mathrm{P}$ balance. The effects of $P$ deficiency were amplified by excess $\mathrm{Ca}$.

In experiment 2, two diets containing $1.5 \mathrm{~g}$ of $\mathrm{P} / \mathrm{kg} \mathrm{DM}$ and poor (LPLCa) or rich (LPHCa) in Ca were compared to a control diet (NPNCa). The two low-P diets did not produce any evident signs of deficiency and thus permitted minimal endogenous fecal loss of $P$ to be evaluated at $24 \mathrm{mg} / \mathrm{kg}$ of live weight/day. This result confirms the figure adopted by INRA (1978) as the minimal maintenance requirement for $P$ in sheep.

\section{Introduction.}

Feeding a phosphorus-deficient diet has harmful effects on appetite, phosphatemia, growth and bone mineralization. These effects are amplified by the intake of excess calcium. In spite of numerous studies analyzing the influence of phosphorus deficiency in sheep (Preston and Pfander, 1964 ; Young, Lofgreen and Luick, 1966 ; Compère, 1967 ; Nel and Moir, 1974 ; Field, Suttle and Nisbet, 1975 ; Bonilla, 1976), the minimal requirement for phosphorus in this species is still the object of a strong controversy, resulting mainly from differences in the estimation of minimal endogenous losses.

It is now admitted that endogenous fecal excretion of $P$ is not constant, representing an intestinal pathway for the excretion of excess absorbed $P$. This excretion into the digestive tract is higher when $P$ intake is high and when there is more salivary secretion, i.e. if the ration has a high fiber content (Guéguen, 1963 ;

(*) For reprints. 
Compère, 1967 ; Tomas, 1974), and compensates urinary loss which is usually very low in ruminants. Only the incompressible part of endogenous fecal loss corresponds to the minimal maintenance requirement (Guéguen and Durand, 1976 ; Field et al., 1982). It is evident that this minimal need must be compatible with normal phosphatemia, i.e. with the normal physiological behavior of the animal, and with a good return by the saliva of the $P$ needed by the rumen microorganisms. To define French recommendations regarding $P$ requirements for sheep (INRA, 1978), one of us (L.G.) proposed a minimal figure of $28 \mathrm{mg}$ of endogenous fecal $\mathrm{P} / \mathrm{kg}$ of live weight/day. The Agricultural Research Council (1980) suggested a minimal figure of $12 \mathrm{mg} / \mathrm{kg} / \mathrm{day}$, while Braithwaite (1981) considered the minimal endogenous fecal excretion of sheep given a hay diet and concentrated feed to be $35 \mathrm{mg} / \mathrm{kg} / \mathrm{day}$.

The aim of the present study was twofold : (1) to determine the optimal conditions for measuring the minimal maintenance requirement for $P$ in the growing lamb showing no apparent signs of $P$ deficiency, and (2) to measure the endogenous fecal excretion of $P$ in sheep fed a semi-purified low- $P$ diet with an usual level of cellulose $(26 \%)$ and poor or rich in $\mathrm{Ca}$. The effects of a marginal $P$ deficiency with or without excess $\mathrm{Ca}$ on metabolism in the rumen, and particularly on the utilization of non-protein nitrogen, will be reported in a future paper.

\section{Material and methods.}

\section{Animals and diets.}

Two different experiments were carried out on castrated lle-de-France ram lambs given the same type of purified diet and wheat straw. Urea was the only source of nitrogen in these diets (table 1) and varying amounts of $P$ and Ca were added in the form of dicalcium phosphate and calcium carbonate to obtain the levels of $\mathrm{P}$ and $\mathrm{Ca}$ shown on table 2.

In experiment 1 , the overall effects of low intake $1.2 \mathrm{~g}$ or $1.3 \mathrm{~g}$ of $P / \mathrm{kg}$ of total dietary DM) were studied in the presence of a deficiency $(2.7 \mathrm{~g} / \mathrm{kg} \mathrm{DM})$ or an excess $(10.9 \mathrm{~g} / \mathrm{kg} \mathrm{DM})$ of Ca (LPLCa and LPHCa diets, respectively). In experiment 2, two low-P diets $(1.5 \mathrm{~g} / \mathrm{kg}$ total $D M)$, poor $(3.2 \mathrm{~g} / \mathrm{kg} \mathrm{DM})$ or rich $(12.4 \mathrm{~g} / \mathrm{kg} \mathrm{DM})$ in Ca (LPLCa and LPHCa diets, respectively), were compared to a control diet (NPNCa) having normal levels of $P(3.6 \mathrm{~g} / \mathrm{kg} \mathrm{DM})$ and $\mathrm{Ca}(7.5 \mathrm{~g} / \mathrm{kg}$ DM).

Experiment 1. - Two lots (4 lambs each) of 6-month old lambs, weighing an average of $40 \mathrm{~kg}$ at the beginning of the experiment, were given in two meals $1200 \mathrm{~g} /$ day of a purified diet (LPLCa or LPHCa) in 5-mm granules and $120 \mathrm{~g}$ of chopped wheat straw $(0.6 \mathrm{~g}$ of $\mathrm{P}$ and $3.2 \mathrm{~g}$ of $\mathrm{Ca} / \mathrm{kg} \mathrm{DM})$; water was available ad libitum.

Experiment 2. - Three lots (4 lambs each) of 4-month old lambs weighing an average of $30 \mathrm{~kg}$ at the beginning of the experiment, were given in two meals $1100 \mathrm{~g} /$ day of one of three following purified diets : NPNCa, LPLCa or LPHCa (table 1) and $120 \mathrm{~g}$ of chopped wheat straw (1.1 g of $P$ and $4.2 \mathrm{~g}$ of $\mathrm{Ca} / \mathrm{kg} \mathrm{DM})$; water was available ad libitum. 
TABLE 1

Ingredient composition of the purified diets.

\begin{tabular}{|c|c|c|c|c|c|}
\hline & \multicolumn{2}{|c|}{ Experiment 1} & \multicolumn{3}{|c|}{ Experiment 2} \\
\hline & LPLCa & $\mathrm{LPHCa}$ & NPNCa & LPLCa & $\mathrm{LPHCa}$ \\
\hline Cellulose & 27.4 & 26.4 & 26.1 & 26.6 & 25.3 \\
\hline Maize starch & 38.0 & 37.0 & 38.0 & 38.6 & 38.0 \\
\hline Cerelose ... & 24.0 & 24.0 & 24.0 & 24.0 & 24.0 \\
\hline Urea .... & 4.4 & 4.4 & 4.4 & 4.4 & 4.4 \\
\hline Maize oil & 3.0 & 3.0 & 3.0 & 3.0 & 3.0 \\
\hline Choline chloride & 0.1 & 0.1 & 0.1 & 0.1 & 0.1 \\
\hline \multirow{2}{*}{$\begin{array}{c}\text { Mineral and vitamin mix- } \\
\text { ture }\left(^{*}\right) \ldots \ldots \ldots \ldots \ldots \ldots\end{array}$} & & & & & \\
\hline & 3.1 & 5.1 & 4.4 & 3.3 & 5.2 \\
\hline
\end{tabular}

(*) Supplying (per kg air-dried feed) variable amounts of $\mathrm{CaHPO}_{4}, 2 \mathrm{H}_{2} \mathrm{O}$ and $\mathrm{CaCO}_{3}$ and constant amounts of : $\mathrm{KCl}, 5.0 \mathrm{~g} ; \mathrm{Na}_{2} \mathrm{SO}_{4}, 6.0 \mathrm{~g} ; \mathrm{K}_{2} \mathrm{SO}_{4}, 2.3 \mathrm{~g} ; \mathrm{K}_{2} \mathrm{CO}_{3}, 2.7 \mathrm{~g} ; \mathrm{MgSO}_{4} .7 \mathrm{H}_{2} \mathrm{O}, 4.5 \mathrm{~g}$; $\mathrm{Mg}(\mathrm{OH})_{2}, 3.0 \mathrm{~g} ; \mathrm{FeSO}_{4} .7 \mathrm{H}_{2} \mathrm{O}, 730 \mathrm{mg} ; \mathrm{MnSO}_{4} \cdot \mathrm{H}_{2} \mathrm{O}, 380 \mathrm{mg} ; \mathrm{ZnSO}_{4} . \mathrm{H}_{2} \mathrm{O}, 250 \mathrm{mg} ; \mathrm{CuSO}_{4} .5 \mathrm{H}_{2} \mathrm{O}$, $22 \mathrm{mg}$; $\mathrm{CoSO}_{4} .7 \mathrm{H}_{2} \mathrm{O}, 4 \mathrm{mg} ; \mathrm{Kl}, 1 \mathrm{mg} ; \mathrm{Na}_{2} \mathrm{SeO}_{3}, 0.4 \mathrm{mg} ;\left(\mathrm{NH}_{4}\right)_{6} \mathrm{Mo}_{7} \mathrm{O}_{24} .4 \mathrm{H}_{2} \mathrm{O}, 0.3 \mathrm{mg}$; vitamin A, $15000 \mathrm{UI}$; vitamin $\mathrm{D}_{3}, 500 \mathrm{UI}$; vitamin $\mathrm{E}, 50 \mathrm{UI}$; thiamine chlorhydrate, $12 \mathrm{mg}$.

TABLE 2

Organic matter, nitrogen, phosphorus and calcium contents (analysis) of the diets (g per $\mathrm{kg}$ dry matter).

\begin{tabular}{|c|c|c|c|c|c|}
\hline & \multicolumn{2}{|c|}{ Experiment 1} & \multicolumn{3}{|c|}{ Experiment 2} \\
\hline & LPLCa & LPHCa & NPNCa & LPLCa & LPHCa \\
\hline 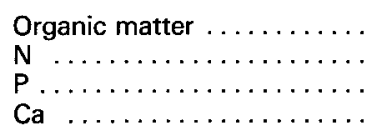 & $\begin{array}{r}970.1 \\
25.7 \\
1.3 \\
2.7\end{array}$ & $\begin{array}{r}949.2 \\
24.8 \\
1.2 \\
10.9\end{array}$ & $\begin{array}{r}961.7 \\
22.3 \\
3.6 \\
7.5\end{array}$ & $\begin{array}{r}971.9 \\
25.5 \\
1.5 \\
3.2\end{array}$ & $\begin{array}{r}953.1 \\
22.1 \\
1.5 \\
12.4\end{array}$ \\
\hline
\end{tabular}

\section{Experimental procedure.}

The lambs were first adapted gradually for 3 weeks to a purified diet containing urea; then, after they had been divided into homogeneous lots according to mean weight, they were adapted again to the various experimental diets for 4 weeks, one of which they spent in metabolism cages.

During the balance periods, we measured the amounts of purified diet and straw ingested each day and a representative sample was taken for analysis. The feces and urine were collected separately over 5 days. The blood was sampled every 5 days.

Experiment 1. - The two 10-day balance periods were separated by a 14 day interval in both lots of 4 animals each. We measured the ingestion and fecal excretion of dry matter, $\mathrm{P}$ and $\mathrm{Ca}$. $\mathrm{P}$ and $\mathrm{Ca}$ in the urine were not assayed. 
Experiment 2. - The same parameters as those in experiment 1 were measured in the three lots of 4 animals each during a classical 10-day balance period. Besides this, urinary excretion of $\mathrm{P}$ and $\mathrm{Ca}$ was measured. At the end of this period, we used the isotopic dilution method (Lofgreen and Kleiber, 1954) described by Guéguen (1962) on 3 animals per lot to determine endogenous fecal excretion of $P$. After subcutaneous injection of $37 \mathrm{MBq}$ of ${ }^{32} \mathrm{P}$ in the form of disodium phosphate, blood samples were taken on days 8, 11 and 14 and fecal samples every day between days 9 and 15. The calculation of the ratio of specific radioactivity of plasma and fecal $P$ took into account a 2-day difference between the maximum in the plasma and that in the feces.

\section{Analytical methods.}

Samples of the diet and feces were ashed in an oven at $550{ }^{\circ} \mathrm{C}$ and then put in an acid solution before determination of $\mathrm{P}$ and $\mathrm{Ca} ; \mathrm{P}$ and $\mathrm{Ca}$ were also determined in previously acidified samples of urine after simple dilution. $P$ was assayed by the vanado-molybdate procedure and $\mathrm{Ca}$ was determined by flame emission spectrophotometry (Eppendorf apparatus).

The blood samples were centrifuged immediately and the plasma was deproteinized by trichloracetic acid (10\%). Inorganic phosphorus was assayed by the method of Chen, Toribara and Warner (1956).

Radioactivity was measured in deproteinized plasma and in diluted solutions of fecal ash by the Cerenkov effect using a liquid scintillation counter (Beckman LS 9000).

Student's two-tailed t-test was used to compare the means.

\section{Results.}

1. Dietary intake and animal growth. - In experiment 1, the excess of $\mathrm{Ca}$ significantly decreased $(P<0.05)$ the appetite of the lambs : the levels of dry matter ingested were $1107 \pm 38$ and $937 \pm 71 \mathrm{~g} /$ day for the LPLCa and LPHCa diets, respectively.

In experiment 2, the amounts of ingested dry matter were $1047 \pm 15$, $1033 \pm 37$ and $1040 \pm 38 \mathrm{~g} /$ day for the NPNCa, LPLCa and LPHCa diets, respectively. The effect of the $P$ deficiency on appetite did not appear in this experiment because the deficiency was less pronounced $11.5 \mathrm{~g} / \mathrm{kg}$ instead of $1.2 \mathrm{~g} / \mathrm{kg}$ ) and also because the amount of diet offered was rationed in order to limit refusals.

It is difficult to estimate exactly daily weight gain during a balance period. Over 2 months, mean daily weight gain was the following (in $\mathrm{g}$ ) :

Experiment 1 : LPLCa 105, LPHCa 70,

Experiment 2 : NPNCa 180, LPLCa 130, LPHCa 130.

These growth rates were relatively low and clearly decreased under the effect of $P$ deficiency.

2. Phosphatemia. - The mean levels of plasma inorganic $P$ observed after 5 weeks of adaptation to the diets are shown on figure 1. In experiment 1, 


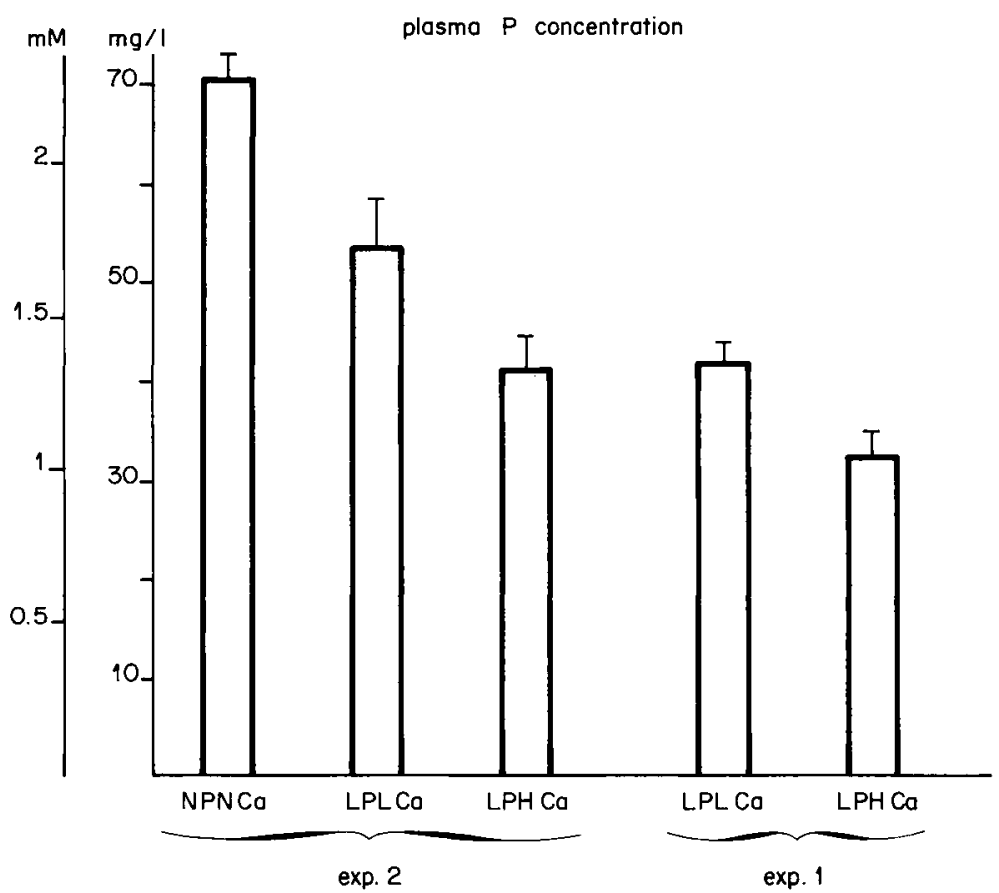

FIG. 1. - Inorganic phosphorus concentration in the plasma of sheep in Experiment 1 $(1.2 \mathrm{~g} \mathrm{P} / \mathrm{kg} \mathrm{D.M.})$ and in Experiment $2(1.5 \mathrm{~g} \mathrm{P} / \mathrm{kg} \mathrm{D.M.})$.

hypophosphatemia was particularly marked with the LPHCa diet $(3.30 \pm 0.19 \mathrm{mg} / \mathrm{dl})$ and significantly more so $(P<0.005)$ than with the LPLCa diet $(4.27 \pm 0.11 \mathrm{mg} / \mathrm{dl})$.

In experiment 2, low- $P$ intake also significantly decreased phosphatemia compared to the control diet : $5.34 \pm 0.50 \mathrm{mg} / \mathrm{dl}$ for lot LPLCa $(\mathrm{P}<0.01)$ and $4.17 \pm 0.29 \mathrm{mg} / \mathrm{dl}$ for lot LPHCa $(\mathrm{P}<0.001) \mathrm{vs} 7.05 \pm 0.23 \mathrm{mg} / \mathrm{dl}$ for lot NPNCa. As in experiment 1 , excess $\mathrm{Ca}$ amplified the hypophosphatemia due to $\mathrm{P}$ deficiency.

3. Utilization of phosphorus. - The results of $P$ balance for experiment 1 are shown on table 3 and those of experiment 2 on table 4.

Urinary $P$ excretion was always low, except in one lamb fed the NPNCa diet $(0.44 \mathrm{~g}$ of $\mathrm{P} /$ day). As a result, apparent absorption was synonymous with retention, being particularly low or even negative with severe deficiency (experiment 1). In experiment 2 (table 4), P retention was high for the NPNCa diet $(0.95 \mathrm{~g} /$ day) and relatively low $(0.44$ and $0.41 \mathrm{~g} /$ day) for the LPLCa and LPHCa diets, respectively, although these values were clearly higher than those found in experiment 1.

Endogenous fecal excretion of P was high in the NPNCa lot $160.5 \mathrm{mg} / \mathrm{kg}$ live weight/day) and much lower in the two low-P lots $(24.5$ and $22.6 \mathrm{mg} / \mathrm{kg} / \mathrm{day})$. The true absorption coefficient of $\mathrm{P}$ was very high and significantly lower $(P<0.05)$ with the Ca-rich diet. 
TABLE 3

The effect of different levels of phosphorus and calcium intakes on the apparent absorption of phosphorus and calcium in growing sheep (Experiment 1).

\begin{tabular}{|c|c|c|c|c|}
\hline & & LPLCa & LPHCa & $\begin{array}{c}\text { Significance } \\
\text { of the difference }\end{array}$ \\
\hline$P$ & $\begin{array}{l}\text { Intake }(\mathrm{g} / \mathrm{d}) \ldots \ldots \ldots \ldots \\
\text { Feces }(\mathrm{g} / \mathrm{d}) \ldots \ldots \ldots \ldots \ldots \\
\text { app. Absorption }(\mathrm{g} / \mathrm{d}) \ldots \ldots \\
\text { app. Absorption }(\%) \ldots \ldots\end{array}$ & $\begin{array}{l}1.37 \pm 0.05 \\
1.26 \pm 0.06 \\
0.11 \pm 0.04 \\
8.0 \pm 3.1\end{array}$ & $\begin{array}{r}1.06 \pm 0.08 \\
1.07 \pm 0.06 \\
-0.01 \pm 0.04 \\
-\end{array}$ & $\begin{array}{l}* * \\
* \\
*\end{array}$ \\
\hline $\mathrm{Ca}$ & $\begin{array}{l}\text { Intake }(\mathrm{g} / \mathrm{d}) \ldots \ldots \ldots \ldots \\
\text { Feces }(\mathrm{g} / \mathrm{d}) \ldots \ldots \ldots \ldots \ldots \\
\text { app. Absorption }(\mathrm{g} / \mathrm{d}) \ldots \ldots \\
\text { app. Absorption }(\%) \ldots \ldots\end{array}$ & $\begin{array}{l}2.96 \pm 0.12 \\
2.46 \pm 0.12 \\
0.50 \pm 0.08 \\
16.9 \pm 2.8\end{array}$ & $\begin{array}{c}9.51 \pm 0.78 \\
8.30 \pm 0.54 \\
1.21 \pm 0.32 \\
12.7 \pm 2.7\end{array}$ & $\begin{array}{l}* * \\
* * \\
* \\
\text { NS }\end{array}$ \\
\hline
\end{tabular}

Mean \pm SEM $; \mathbf{n}=4 .^{* *}: 0.01 ;{ }^{*}: 0.05 ;$ NS : non significant.

TABLE 4

The effect of different levels of phosphorus and calcium intakes on phosphorus metabolism in growing sheep (Experiment 2).

\begin{tabular}{|c|c|c|c|}
\hline & NPNCa & LPLCa & LPHCa \\
\hline Intake $(g / d)$ & $3.65 \pm 0.02^{(a)}$ & $1.52 \pm 0.05^{(a)}$ & $1.55 \pm 0.07^{(b)}$ \\
\hline Feces $(\mathrm{g} / \mathrm{d})$ & $2.70 \pm 0.07(a)$ & $1.08 \pm 0.02^{(b)}$ & $1.14 \pm 0.05^{(b)}$ \\
\hline Urine $(\mathrm{g} / \mathrm{d})$ & $0.11 \pm 0.11^{(*)}$ & traces & traces \\
\hline app. Absorption $(\mathrm{g} / \mathrm{d})$ & $0.95 \pm 0.07^{(a)}$ & $0.44 \pm 0.05^{(b)}$ & $0.41 \pm 0.08(\mathrm{bc})$ \\
\hline app. Absorption (\%). & $26.0 \pm 1.9$ (a) & $29.0+2.5^{(a)}$ & $26.4+4.6^{(a)}$ \\
\hline Endogenous fecal loss $(\mathrm{g} / \mathrm{d})$ & $2.07 \pm 0.03^{(a)}$ & $0.84 \pm 0.02^{(b)}$ & $0.78+0.05^{(b)}$ \\
\hline Endogenous fecal loss $(\mathrm{mg} / \mathrm{kg} / \mathrm{d})$.. & $60.5 \pm 1.6(a)$ & $24.5 \pm 0.6^{(b)}$ & $22.6 \pm 1.6^{(b)}$ \\
\hline True absorption $(\mathrm{g} / \mathrm{d}) \ldots \ldots \ldots$ & $3.02 \pm 0.05^{(a)}$ & $1.28 \pm 0.05^{(b)}$ & $1.19 \pm 0.07^{(b)}$ \\
\hline True absorption (\%) . . . . . . . & $82.7 \pm 1.2^{(\mathrm{d})}$ & $84.2 \pm 2.1^{(d)}$ & $76.8 \pm 2.5^{(e)}$ \\
\hline
\end{tabular}

$\left.{ }^{*}\right) 0.44 \mathrm{mg}$ of $\mathbf{P}$ per day in the urine of one animal.

Mean \pm SEM $; n=4$. Values with different superscripts in the same line differ at $P<0.01$ la, $b$, c) or at $P<0.05$ (d, e). Values for endogenous loss and true absorption were obtained from 3 animals in each treatment ; the mean was used for the fourth.

4. Calcium utilization. - The results of $\mathrm{Ca}$ balance are shown on table 3 for experiment 1 and on table 5 for experiment 2.

Urinary $\mathrm{Ca}$ excretion was low but not negligible (table 5). Apparent absorption and retention increased as intakes increased but, in experiment 2 , the amount of $\mathrm{Ca}$ retained from the LPHCa diet was not significantly higher than that of the NPNCa diet, $\mathrm{P}$ deficiency being a limiting factor of Ca retention.

Endogenous fecal excretion of $\mathrm{Ca}$ has been calculated (table 5) using a theoretical mean of $18 \mathrm{mg} / \mathrm{kg}$ live weight/day (Braithwaite, 1982). Thus, the coefficient of true absorption decreased in a linear way when $\mathrm{Ca}$ intake increased. 
TABLE 5

The effect of different levels of phosphorus and calcium intakes on calcium metabolism in growing sheep (Experiment 2).

\begin{tabular}{|c|c|c|c|}
\hline & NPNCa & LPLCa & LPHCa \\
\hline Intake $(g / d)$ & $7.46 \pm 0.02^{(\mathrm{a})}$ & $3.35 \pm 0.12^{(b)}$ & $12.04 \pm 0.37^{(a)}$ \\
\hline Feces $(g / d)$ & $5.90 \pm 0.23^{\text {(a) }}$ & $2.67 \pm 0.09(b)$ & $9.87 \pm 0.58^{(c)}$ \\
\hline Urine $(\mathrm{g} / \mathrm{d})$ & $0.28 \pm 0.07$ (a) & $0.22 \pm 0.04^{(a)}$ & $0.50 \pm 0.06^{(b)}$ \\
\hline Retention $(\mathrm{g} / \mathrm{d})$ & $1.28 \pm 0.18^{(a)}$ & $0.46 \pm 0.15^{(b)}$ & $1.67 \pm 0.29^{(a)}$ \\
\hline app. Absorption $(\mathrm{g} / \mathrm{d})$ & $1.56 \pm 0.23^{(a)}$ & $0.68 \pm 0.10^{(b)}$ & $2.17 \pm 0.28^{(a)}$ \\
\hline app. Absorption (\%) . & $20.9 \pm 3.1^{(a)}$ & $20.3 \pm 2.8^{(a)}$ & $18.0 \pm 2.8^{(a)}$ \\
\hline Endogenous fecal loss $\left(^{*}\right)(g / d)$ & 0.62 & 0.62 & 0.61 \\
\hline True absorption $(\mathrm{g} / \mathrm{d}) \ldots \ldots \ldots \ldots$ & 2.18 & 1.30 & 2.78 \\
\hline True absorption $(\%) \ldots \ldots$ & 29.2 & 38.8 & 23.1 \\
\hline
\end{tabular}

(*) Calculated using a theoretical value of $18 \mathrm{mg} / \mathrm{kg} / \mathrm{d}$.

Mean $\pm S E M ; n=4$. Values with different superscripts in the same line differ at $P<0.01$.

\section{Discussion.}

The figures adopted in the latest report of the Agricultural Research Council (A.R.C., 1980) for the minimal maintenance requirement of $P$ in sheep are very low and need to be checked with animals fed a low-P diet.

It seems clear that the conditions of experiment $1(1.2 \mathrm{~g}$ of $P / \mathrm{kg} \mathrm{DM})$ in the present study are those of a severe $P$ deficiency that was manifested by a decrease in appetite, hypophosphatemia and a very low or negative $\mathrm{P}$ balance incompatible with normal animal growth. The amounts of diet ingested spontaneously were lower than those recorded by Beaumatin (1981) in 12 lambs of the same age fed an identical diet but with normal $\mathrm{Ca}$ and $\mathrm{P}$ levels (1 $193 \pm 11 \mathrm{~g}$ of $\mathrm{DM} /$ day).

These results agree well with those of authors studying $P$ deficiency (Preston and Pfander, 1964 ; Bonilla, 1976 ; Gartner et al., 1982) and associated Ca excess (Nel and Moir, 1974 ; Field, Suttle and Nisbet, 1975).

Contrary to the hypothesis of Field, Suttle and Nisbet (1975), the decrease in appetite resulting from $\mathrm{P}$ deficiency associated with $\mathrm{Ca}$ excess does not appear to be due, in the present case, to a drop in DM digestibility (71.1\% for both diets), which was not reported either by Preston and Pfander (1964), Nel and Moir (1974) or Witt and Owens (1983). This decrease in appetite would rather seem to be the result of a metabolic regulation (Henry, Guéguen and Rérat, 1978), although neither transit rate (Field, 1981) nor dilution rate in the rumen (Durand et al., 1983) can be excluded.

Even though we could not study the effect of the diet on appetite in experiment 2 because the amount of diet given was limited to ensure constant intake, the level of $1.5 \mathrm{~g}$ of $\mathrm{P} / \mathrm{kg} \mathrm{DM}$ did not appear to have a negative effect on food intake.

Phosphatemia was lower when dietary $P$ levels were low (fig. 1), as previously observed by many authors (Preston and Pfander, 1964 ; Young et al., 
1966 ; Farries and Krasnodebska, 1972 ; Bonilla, 1976 ; Field et al., 1982 ; Durand et al., 1982). The decrease in phosphatemia was accentuated by an excess of $\mathrm{Ca}$, as reported by Nel and Moir (1974), Field, Suttle and Nisbet (1975) and Durand et al. (1982). This effect of excess $\mathrm{Ca}$ could be the result of an hormonal reaction (parathyroid hormone and/or calcitonin) blocking bone resorption. If we admit that the lower threshold of normal phosphatemia is about $4 \mathrm{mg} / \mathrm{dl}$, it is clear that the diet containing $1.2 \mathrm{~g}$ of $\mathrm{P} / \mathrm{kg}$ (experiment 1 ) leads to hypophosphatemia ; this did not occur with the diet containing $1.5 \mathrm{~g} / \mathrm{kg}$ (experiment 2), except when there was an excess of $\mathrm{Ca}$. The effect of $\mathrm{P}$ deficiency on phosphatemia is more pronounced in growing lamb (experiment 1) than in adult sheep given an identical diet (Durand et al., 1982).

Without an LPNCa diet we could not study the effect of $P$ deficiency on $\mathrm{Ca}$ metabolism. However, if $\mathrm{Ca}$ and $\mathrm{P}$ are retained in a normal ratio of $1.5: 1$ in sheep given the NPNCa diet, this ratio is much higher in sheep given the LPHCa diet. This suggest that a low level of $\mathrm{P}$ did not prevent a normal amount of $\mathrm{Ca}$ from being retained when the diet contained a high level of $\mathrm{Ca}$ (table 5). On the contrary, both LPLCa diets were too deficient in $\mathrm{Ca}(2.7$ and $3.2 \mathrm{~g} / \mathrm{kg} \mathrm{DM})$ and did not permit Ca retention compatible with normal growth. The endogenous fecal loss of $\mathrm{Ca}$ is independent of dietary $\mathrm{Ca}$ supply but increases with the amount of DM ingested (Braithwaite, 1982). In the present study, it was taken to have a value of $18 \mathrm{mg} / \mathrm{kg}$ live weight/day, which allowed us to check the usual inverse linear relationship between the true absorption coefficient and the amount ingested (table 5). It is interesting to note that this coefficient was $39 \%$ for the low-Ca diet, thus confirming the low values we obtained previously (Guéguen and Durand, 1976) with similar levels and showing that the figure of $68 \%$ adopted by A.R.C. (1980) is an overestimation.

The main interest of the present study is that it permitted us to study the regulation of $P$ metabolism and evaluate the minimal maintenance requirement in animals given a low-P diet and in normal physiological conditions such as those in experiment $2(1.5 \mathrm{~g}$ of $\mathrm{P} / \mathrm{kg} \mathrm{DM})$. Indeed, it is clear that a level of $1.2 \mathrm{~g} / \mathrm{kg}$ (experiment 1) was lower than the minimal requirement because it led to a negative $P$ balance, hypophosphatemia and decreased appetite.

With the control diet (NPNCa), phosphatemia was high and urinary $P$ excretion considerable in one of the 4 sheep, showing that the process of excretion into the intestine, particularly by the saliva, was saturated when there was an excess of absorbed $P$ (Compère, 1967; Field, 1981) or that the renal threshold is lower for some animals (Scott and McLean, 1981). Indeed, true $P$ absorption was very high $(82.7 \%)$, all the $P$ being supplied by very available dicalcium phosphate. To allow the excess absorbed $P$ to be eliminated, endogenous fecal excretion was high $(2.07 \mathrm{~g} / \mathrm{day}$ or $60 \mathrm{mg} / \mathrm{kg}$ of live weight/day). This elevated value agrees with previous observations at comparable intake levels (Compère, 1967 ; Guéguen, Foret and Durand, 1976 ; Grace, 1980). It is well known that this endogenous loss is then much higher than the strict maintenance requirement (Guéguen and Durand, 1976).

With both low-P diets $(1.5 \mathrm{~g} / \mathrm{kg})$ of experiment 2 (LPLCA and LPHCa, table 4), true absorption of $P$ remained very high (84.2 and $76.8 \%$ respectively), 
excess Ca having a significantly unfavourable effect $(P<0.05)$. Urinary excretion being negligible and $P$ retention low but positive, these two diets, which obviated the evident signs of $P$ deficiency, could be used to estimate minimal endogenous fecal losses. The resulting figures $(24.5$ and $22.6 \mathrm{mg} / \mathrm{kg} / \mathrm{day})$ agree with those of Young, Lofgreen and Luick (1966) and Annenkov et al. (1972) obtained in similar conditions.

These figures are slightly lower than the mean of $28 \mathrm{mg}$ that we had adopted to calculate the maintenance requirement of sheep (INRA, 1978) but they are double the figure of $12 \mathrm{mg}$ adopted by A.R.C. (1980) and recently confirmed by Field et al. (1982) for growing sheep.

Such divergencies in the estimation of minimal endogenous fecal loss of $P$ may be due to methodology or experimental conditions. It is admitted that extrapolation of fecal excretion to zero $P$ supply underestimates endogenous loss and the isotopic dilution method is more sure. With this method, the ratio of $P$ specific radioactivity in the plasma and feces is calculated taking into account the delay in peak between the plasma and feces which may vary from 1 to 3 days, depending on the diet. The choice of the number of days of peak delay in fecal radioactivity compared to plasma radioactivity could be a source of error. However, this error would be low because adopting a delay of 2 instead of 3 days entrains only a $7 \%$ overestimation of endogenous fecal loss.

On the other hand, experimental conditions constitute the main cause of divergence. Thus, the rare low figures of endogenous fecal $P$ loss measured in growing lambs were obtained in abnormal physiological conditions : decreased appetite, arrest of growth and hypophosphatemia (Preston and Pfander, 1964), previous depletion or very severe $P$ deficiency with bone disorders (Young, Lofgreen and Luick, 1966), decrease in plasma P, rickets or osteoporosis (Field et al., 1982). According to Field (1983), there may be an inverse relationship between the maintenance requirement for $\mathrm{P}$ and the absorbability of dietary $\mathrm{P}$, endogenous fecal loss being low when absorbability is high. However, this would not explain our disagreement because, in our experiment, $P$ absorbability is always very high ( 77 to $84 \%$ ).

In conclusion, minimal endogenous fecal loss of $P$ measured in growing lambs given a low-P diet and in normal physiological conditions would be about $24 \mathrm{mg} / \mathrm{kg} / \mathrm{day}$, leading to a maintenance requirement closer to the one proposed by INRA (1978) than to the low figure adopted by A.R.C. (1980).

Reçu en mai 1983.

Accepté en août 1983.

Résumé. Utilisation du phosphore et du calcium et besoin minimal d'entretien en phosphore chez le mouton en croissance recevant un régime pauvre en phosphore.

Les effets $d^{\prime} u n e$ subcarence en $P$ associée ou non à un excès de Ca ont été étudiés chez 5 lots de 4 moutons en croissance recevant un régime semi-purifié contenant de la cellulose $(25-27 \%)$ et de l'urée comme seule source d'azote.

Dans une première expérience, deux régimes pauvres en $P(1,2 \mathrm{~g}$ par $\mathrm{kg}$ de $\mathrm{MS})$ et pauvre (LPLCa) ou riche en $\mathrm{Ca}$ (LPHCa) ont conduit à une diminution de la 
phosphatémie, une baisse de l'appétit et à un bilan négatif ou nul de $\mathrm{P}$. Les effets de la carence en $\mathrm{P}$ sont aggravés par l'excès de $\mathrm{Ca}$.

Dans une seconde expérience, deux régimes contenant $1,5 \mathrm{~g}$ de $\mathrm{P}$ par $\mathrm{kg}$ de $\mathrm{MS}$ et pauvre ( $\mathrm{LPLCa}$ ) ou riche ( $\mathrm{LPHCa}$ ) en Ca ont été comparés à un régime témoin (NPNCa). Les deux régimes pauvres en $P$ n'ont pas conduit à des signes évidents de carence et ont donc permis d'évaluer à $24 \mathrm{mg} / \mathrm{kg}$ de poids vif par jour la perte fécale endogène minimum de $P$. Ce résultat confirme la valeur adoptée par I'INRA (1978) pour le besoin minimum $d^{\prime}$ entretien en $P$ des moutons.

\section{References}

AGRICULTURAL RESEARCH COUNCIL, 1980. The nutrient requirements of ruminant livestock, Commonwealth Agricultural Bureau, London.

ANNENKOV B. N., MADISON V. L., DROZDENKO A. D., LOBODIN N. G., 1972. Sel'skokhoz. Biol., 7, 388-394 (in russian).

BEAUMATIN P., 1981. Influence du phosphore alimentaire sur la digestion et la protéosynthèse microbiennes dans le rumen du mouton. Thes. Univ. Toulouse, $110 \mathrm{pp}$.

BONILLA S. E., 1976. Phosphorus in the nutrition of sheep : composition of body fluids, microbial fermentation and feed intake. Thes., Davis Univ., California, 176 pp.

BRAITHWAITE G. D., 1981. Effect of 1 alpha-hydroxycholecalciferol on calcium and phosphorus metabolism in sheep given high or low calcium diets. J. agric. Sci. Camb., 96, 291-299.

BRAITHWAITE G. D., 1982. Endogenous faecal loss of calcium by ruminants. J. agric. Sci. Camb., 99, 355-358.

CHEN P. S. Jr., TORIBARA T. Y., WARNER H., 1956. Microdetermination of phosphorus. Anal. Chem., 28, 1756-1758.

COMPERE R., 1967. L'étude de l'équilibre phosphocalcique du régime basée sur les variations du métabolisme phosphoré. Les Presses agronomiques de Gembloux, A.S.B.L., J. Duculot S. A., Gembloux, 132 pp.

DURAND M., BERTIER B., HANNEQUART G., GUÉGUEN L., 1982. Influence d'une subcarence en phosphore et d'un excès de calcium alimentaire sur la phosphatémie et les teneurs en phosphore et calcium des contenus de rumen du mouton. Reprod. Nutr. Dévelop., 22, 865879.

DURAND M., BOXEBELD A., DUMAY C., BEAUMATIN P., 1983. Influence of the level of dietary phosphorus on urea utilization by rumen microorganisms in lambs. 4th int. Symp. on Protein Metabolism and Nutrition, Coll. INRA. INRA Publ., Versailles.

FARRIES F. E., KRASNODEBSKA J., 1972. Untersuchungen über die Verwertung von Harnstoff beim Wiederkaüer. Zum Einfluss unterschiedlicher P. Versorgung auf den N. Stoffwecksel bei ausschliesslicher NPN - Zufuhr. Z. Tierphysiol. Tierernähr. Futtermitt., 30, 33-47.

FIELD A. C., 1981. Some thoughts on dietary requirements of macro-elements for ruminants. Proc. Nutr. Soc., 40, 267-272.

FIELD A. C., 1983. Maintenance requirements of phosphorus and absorbability of dietary phosphorus in sheep. J. agric. Sci. Camb., 85, 435-442.

FIELD A. C., SUTTLE N. F., NISBET D. I., 1975. Effects of diets low in calcium and phosphorus on the development of growing lambs. J. agric. Sci. Camb., 85, 435-442.

FIELD A. C., COOP R. L., DINGWALL R. A., MUNRO C. S., 1982. The phosphorus requirements for growth and maintenance of sheep. J. agric. Sci. Camb., 99, 311-317.

GARTNER R. J. W., MURPHY G. M., HOEY W. A., 1982. Effects of induced, subclinical phosphorus deficiency on feed intake and growth of beef heifers. J. agric. Sci. Camb., 98, 28-30.

GRACE N. D., 1980. Effect of increasing phosphorus intake on the $P$ fecal endogenous loss in the sheep. Proc. N. Z. Soc. anim. Prod., 40, 221-225.

GUÉGUEN L., 1962. L'utilisation digestive réelle du phosphore du foin de luzerne par le mouton en croissance, mesurée à l'aide de ${ }^{32} \mathrm{P}$. Ann. Biol. anim. Bioch. Biophys., 2, 143-149. 
GUÉGUEN L., 1963. Influence de la nature du régime alimentaire sur l'excrétion fécale de phosphore endogène chez le veau. Ann. Biol. anim. Bioch. Biophys., 3, 243-253.

GUĖGUEN L., 1978. Eléments minéraux majeurs, 129-142. In Alimentation des Ruminants. INRA Publ., Versailles.

GUÉGUEN L., DURAND M., 1976. Utilisation des principaux éléments minéraux du maïs ensilé par le mouton en croissance. Ann. Zootech., 25, 543-549.

GUÉGUEN L., FORET R., DURAND M., 1976. Utilisation du phosphate mono-ammonique chez le Mouton. I. Utilisation comparée du phosphore des phosphates mono-ammonique et monosodique et influence sur le métabolisme du calcium et du magnésium. Ann. Zootech., 25. 111-118.

HENRY Y., GUÉGUEN L., RÉRAT A., 1978. Influence of the level of dietary phosphorus on the voluntary intake of energy and metabolic utilization of nutrients in the growing rat. $B r . J$. Nutr., 42, 127-137.

INSTITUT NATIONAL DE LA RECHERCHE AGRONOMIQUE, 1978. Alimentation des Ruminants. INRA Publ., Versailles.

LOFGREEN G. P., KLEIBER M., 1954. Further studies on the availability of phosphorus in alfalfa hay. $J$. anim. Sci., 13, 258-264.

NEL J. W., MOIR R. J., 1974. The effect of ruminal and duodenal application of different levels of calcium and phosphorus to sheep on semi-purified diets. S.-Afri. J. anim. Sci., 4. 1-20.

PRESTON R. L., PFANDER W.H., 1964. Phosphorus metabolism in lambs fed varying phosphorus intakes. J. Nutr., 83, 369-378.

SCOTT D., Mc LEAN A. F., 1981. Control of mineral absorption in ruminants. Proc. Nutr. Soc., 40, 257-266.

TOMAS F. M., 1974. Phosphorus homeostasis in sheep. II. Influence of diet on the pathway of excretion of phosphorus. Aust. J. agric. Res., 25, 475-483.

YOUNG V. R., LOFGREEN G. P., LUICK J. R., 1966. The effects of phosphorus depletion, and of calcium and phosphorus intake, on the endogenous excretion of these elements by sheep. Br. J. Nutr., 20, 795-805.

YOUNG V. R., RICHARDS W. P. C., LOFGREEN G. P., LUICK J. R., 1966 . Phosphorus depletion in sheep and the ratio of calcium to phosphorus in the diet with reference to calcium and phosphorus absorption. Br. J. Nutr., 20, 783-794.

WITT K. E., OWENS F. N., 1983. Phosphorus : ruminal availability and effects on digestion. J. anim. Sci., 56, 930-937. 